\title{
FACTORS AFFECTING PROFITABILITY OF PHARMACEUTICAL COMPANIES LISTED IN INDONESIA STOCK EXCHANGE
}

\author{
Hasna Ohorella \\ Department of Business Administration, Sekolah Tinggi Ilmu Administrasi Trinitas, Indonesia \\ E-mail: ohorellahasna@yahoo.com
}

\begin{abstract}
Profitability is one of the factors to assess the good and bad of a company's performance. This study aims to analyze empirically the effect of Debt Ratio, Debt to Equity Ratio, and Total Asset Turnover on Return On Asset. The research sample was selected using a purposive sampling method, namely the selection of samples of company shares/stocks during the study period based on certain criteria. Pharmaceutical sub-sector companies those actively present financial reports during the study period in 2012-2016 on the Indonesia Stock Exchange. The data used shows in full that comes from the balance sheet and income statement. The results of the research findings show that there is no effect of Debt Ratio, Debt to Equity Ratio, and Total Asset Turnover on Return on Asset.
\end{abstract}

\section{KEY WORDS}

Debt Ratio, debt to equity ratio, total asset turnover, return on asset.

Every company wants their business to run smoothly and can even develop. To achieve this, certainly costs needed. Capital is a very important thing for a company, because capital is used to finance operations and also develops business. Capital could come from own capital or loan capital or debt. Therefore, determining an optimal capital structure is also important, especially for go public companies in the capital market (Black \& Gilson, 1988; Alti, 2006; Ang et al., 2018; Allen et al., 2018; Roychowdhury \& Srinivasan, 2019).

The pharmaceutical sector is one of the industries supporting economic development in Indonesia. Progress in this sector not only provides input to the Country but also encourages the development of other related industries. Companies or organizations carry out various activities to achieve the goals that have been previously set. In an effort to achieve that goal, the company must be able to operate smoothly and be able to combine all available resources so that it can achieve optimal results and profit levels. The survival of a company is influenced by many things, including the profitability of the company itself. Profitability is one of the factors to assess the good and bad of a company's performance. Return on Assets $(R O A)$ is a profitability ratio used to measure the effectiveness of a company in generating profits by utilizing the total assets it has. The factors that can affect the profitability of a company among others, Debt Ratio (DR), Debt To Equity Ratio (DER) and Total Asset Turnover (TATO), Sales Growth and Company Size.

According to Kasmir (2014), Yuniningsih et al. (2018), Wibowo et al. (2019) profitability ratios are ratios used to assess a company's profits in seeking a profit. This ratio provides a measure of the level of management effectiveness of a company as indicated by profits generated from sales and income (Nezami et al., 2018; Kajananthan \& Velnampy, 2018; Saerang et al., 2018) According to Tandelilin (2010) one of the important in.dicators for assessing company prospects in the future is to see how far the company's profitability grows, so that this ratio is a factor that gets important attention for investors in assessing a company.

In addition, the rate of sales growth can also affect the company's profitability. The higher net sales made by the company can encourage the higher gross profit that can be obtained, so that it can encourage the higher company's profitability. This is in line with the size of a company. With the increasing size of the company, it will reflect the increasing amount of available resources to meet product demand. Besides that, with the increasing 
size of a company, the company has the opportunity to reach a wider market to market its products, thus opening up opportunities for higher profits.

According to Kasmir (2014), Rouf (2015), Nassar (2016), Debt Ratio (DR) is a debt ratio used to measure the ratio between total debt and total assets. In other words, how much the company's assets are financed by debt or how much the company's debt affects the management of assets. From the measurement results, if the ratio is high, it means that funding with debt is increasing, then it is increasingly difficult for companies to obtain additional loans because it is feared that the company is unable to cover its debts with its assets, so if the ratio is low, the smaller the company is financed with debt.

According to Prastomo (2002: 84) in Willana (2012), "DR can also provide an overview of the capital structure owned by the company, so that it can be seen the level of risk of collectible debt," Kasmir (2014) explains that "the results of this ratio will give different meanings to creditors and companies. For banks (creditors), the greater the ratio, the more unprofitable, because the greater the risk borne for failures that may occur in the company". Then it can be concluded that the DR is a ratio used to measure a company's ability to finance short-term and long-term debt.

Similarly, the Debt to Equity Ratio is the ratio of debt to company equity or conditions that indicate the company's ability to fulfill its operational activities using its own capital. That is, the more capital used to fulfill the company's operational activities will reduce the likelihood of a loan, so that it can minimize liabilities in paying interest expenses for the company. According to Gibson (2008) namely "Debt equity ratio is another computation that's determines the entity's long-term debt-paying ability". Meaning that, debt equity ratio is another computation that determines the ability to pay for an entity's long-term debt. According to Sugiyono (2009: 71), states that: This ratio shows the ratio of debt and capital. This ratio is one of the important ratios because it correlates with the problem of trading on equity, which can give a positive and negative influence on the profitability of own capital and the company. Bhandari (1988) mendefinisikan debt to equity ratio, "Measures used in analyzing financial statements to show the amount of collateral available to creditors"

Total Asset Turnover is an activity ratio used to measure how much the effectiveness of the company in using resources in the form of assets. The more efficient the asset user is and the faster the refund is in the form of cash (Abdullah Halim, 2007). Whereas according to (Weston and Brigham, 1989), TATO is the ratio of the last asset manager, measuring the turnover or utilization of all company assets. If the company does not produce enough business volume for the size of the investment in the amount of its total assets, sales must be increased, some assets must be sold or a combination of these steps must be done immediately.

According to Agnes Sawir, (2003: 19) is "the Total Assets Turnover speed in a certain period". Definition of Total Asset Turnover according to Mandu Hanafi (2003: 81) is "This ratio measures how far a company's ability to generate sales is based on the effective use of total assets. Whereas according to Syamsudin (2009: 19) "Total Asset Turnover is a ratio that shows the level of efficiency of the overall use of company assets in generating certain sales volumes. From the above meanings, it can be concluded that Total Asset Turnover is a company's asset turnover due to sales in a certain period.

Table 1 - Debt Ratio, Debt to Equity Ratio, Total Asset Turnover, and Return on Asset in Pharmacy companies listed in the Indonesia Stock Exchange/bursa efek Indonesia (BEI), 2012-20116

\begin{tabular}{|c|c|c|c|c|c|c|c|}
\hline \multirow{2}{*}{ No } & \multirow{2}{*}{ Variable } & \multicolumn{5}{|c|}{ Year } & \multirow{2}{*}{ Average } \\
\cline { 3 - 7 } & & 2012 & 2013 & 2014 & 2015 & 2016 & 388.92 \\
\hline 1 & DR & 418.42 & 390.40 & 407.26 & 383.84 & 344.72 & 274.59 \\
\hline 2 & DER & 245.69 & 284.56 & 275.79 & 272.37 & 294.55 & 777.82 \\
\hline 3 & TATO & 844.47 & 794.46 & 741.17 & 770.87 & 738.16 & 72.200 \\
\hline 4 & ROA & 68.91 & 107.58 & 82.10 & 52.72 & 84.72 & \\
\hline
\end{tabular}

Source: www.idx.co.id (data processed). 
Based on Table 1, it can be concluded that the debt ratio, total asset turnover has decreased and increased every year while the Debt to Equity ratio has increased every year except in 2014 debt to equity has decreased. In 2013-2014 ROA increased from the previous year and decreased in 2015 and increased again in 2016. The Debt ratio declined in 2013 and increased again in 2014 while in 2015-2016 it experienced a decline from the previous year, as well as the total asset turnover in 2013-2016 which declined from the previous year and increased in 2015 and declined again in 2016. This shows a difference that if associated with the existing theory, where in theory it is said that increasing ROA will be in line with the increase in DR, DER, and TATO. Things like this can be seen as a comparison between theories and facts that occur in reality in this study.

Based on the background of the problems described above, it can be concluded that theoretically the debt ratio, debt to equity ratio and total asset turnover are three factors that influence profitability, but in reality there may be other factors that more dominate their influence on profitability and to prove the truth of these three factors can affect profitability of pharmaceutical companies, further research is needed on pharmaceutical companies listed on the Indonesia Stock Exchange.

\section{METHODS OF RESEARCH}

This type of research is quantitative research namely research that emphasizes on the testing of theories through measuring research variables with numbers and analyzing the data with statistical procedures. The research sample was selected using a purposive sampling method, namely the selection of samples of company shares/stocks during the study period. Pharmaceutical sub-sector companies actively present financial statements during the study period in 2012-2016 in the Indonesia Stock Exchange (website www.idx.co.id) which is the official website of Indonesia Stock Exchange/Bursa Efek Indonesia $(\mathrm{BEI})$. Data analysis in this study using multiple linear regressions, to determine how much the influence of the independent variable namely: DR $\left(\mathrm{X}_{1}\right)$, DER $\left(\mathrm{X}_{2}\right)$, TATO $\left(\mathrm{X}_{3}\right)$ on the dependent variable ROA $(Y)$.

$$
Y=a+b_{1} X_{1}+b_{2} X_{2}+b_{3} X_{3}+e
$$

Where: $Y=$ Dependent variable (Return on Asset); $a=$ Constant; $b_{1}, b_{2}, b_{3}=$ Regression Coefficient; $\mathrm{X}_{1}=$ Debt Ratio; $\mathrm{X}_{2}=$ Debt to Equity Ratio; $\mathrm{X}_{3}=$ Total Asset Turnover; $\mathrm{e}=$ Error $/$ Disturbing element.

\section{RESULTS AND DISCUSSION}

To test the feasibility of the regression model used, it must first meet the classic assumption test. There are four important assumptions underlying the classical linear regression model, namely, the variables have a normal distribution, conditional variance is constant or homoschedastic, no autocorrelation, and there is no multicollinearity among the variables that explain.

Normality test is done to test whether the sample taken comes from a population that is normally distributed or not. To see whether the data is distributed normally or not, we can look at the PP Plot graph. A data will be normally distributed if the value of observation probability. In the PP Plot graph, the similarity is aimed at the line of expectation and probability of observation (Santoso and Ashari, 2015:232).

Based on Figure 1 above shows that all existing data are normally distributed, because all data spreads form a diagonal straight line, then the data meets normal assumptions or follows a normality line.

The Heteroscedasticity test aims to test whether the data in the regression model occurred inequality variance from the residuals of one observation to another observation. If the residual variance from one observation to another observation remains, then it is called homoskedasticity if different is called heteroscedasticity. 


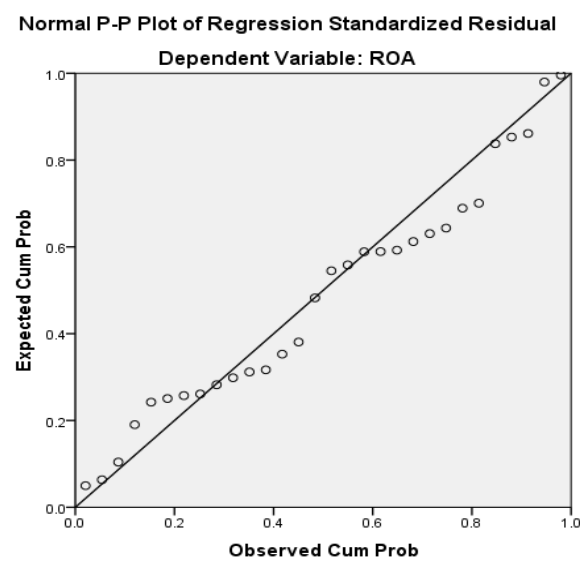

Figure 1 - Normality Test Results (Source: research results; data processed in SPSS)

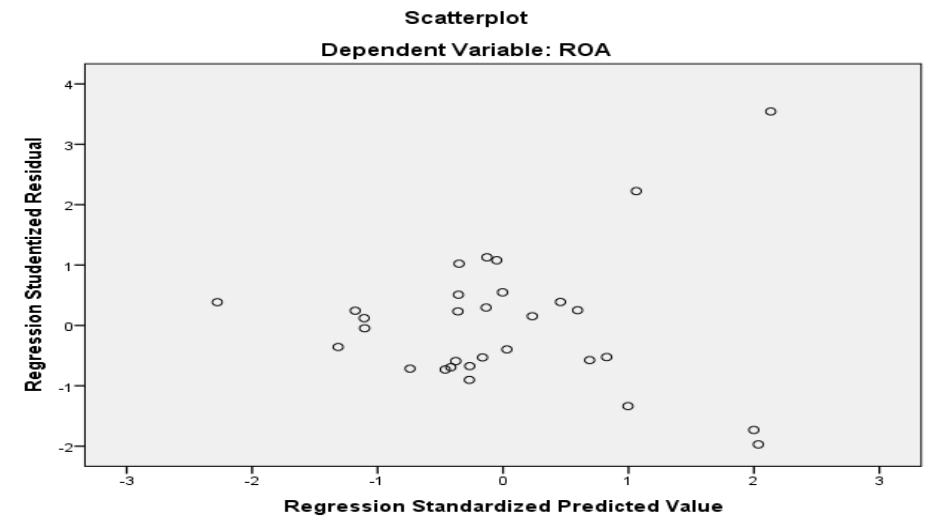

Figure 2 - Heteroscedasticity Test Results

Based on Figure 2 above, it can be seen that the distribution of data is not certain and does not form a specific pattern, and spreads above and below the number 0 on the $Y$ axis, so it can be concluded that the regression model does not have a heteroscedasticity problem.

Multicollinearity test aims to test whether the regression model has a correlation among the independent variables. A good regression model should not have a correlation among the independent variables. Detection of multicolinerity by looking at tolerance and or VIF. A low tolerance value is the same as a high VIF value (VIF $=1$ / tolerance) and indicates the existence of collinearity. The commonly used value is the tolerance value of 0,10 or the same as the VIF value above 10. The level of collinearity that can be tolerated is the tolerance value of 0,10 is equal to the level of multicollinearity of 0,95 .

Table 2 - Multicollinearity Test Results

Coefficients $^{a}$

\begin{tabular}{|c|c|c|c|}
\hline & \multirow{2}{*}{ Model } & \multicolumn{2}{|c|}{ Collinearity Statistics } \\
\hline & & Tolerance & VIF \\
\hline & DR & .425 & 2.354 \\
\hline 1 & DER & .436 & 2.294 \\
\hline & TATO & .937 & 1.068 \\
\hline
\end{tabular}

a. Dependent Variable: roa

Source: research results (Data processed in SPSS).

From the data in Table 2 above, it can be seen that the requirements to pass the multicolinerity test have been fulfilled by all available independent variables, namely tolerance values of not less than 0,10 and VIF (Variance Inflation factor) values of more than 
10. Therefore, it can be concluded that all the independent variables used in this study do not correlate between the independent variables one with the other independent variables.

Autocorrelation test is done to test whether in a linear regression model there is a correlation between error terms in a period with errors in the previous period which usually occur because of using time series data. A good regression model is a regression that is free from autocorrelation (Imam Ghazali, 2006).

One of the ways to detect the presence or absence of autocorrelation is by testing 0 the Durbin Watron test value (DW-Test). The Durbin Watson test is only used for first order autocorrelation and requires an intercept (Constanta) in the regression model and no variable lag among the independent variables.

Table 3 - Autorrelation Test Results

Model Summary

\begin{tabular}{|c|c|}
\hline Model & Durbin-Watson \\
\hline 1 & $2.338^{\mathrm{a}}$ \\
\hline
\end{tabular}

a. Predictors: (Constant), TATO, DER, DR.

b. Dependent Variable: ROA.

Source: research results (Data processed in SPSS).

Based on Table 3, the value of Durbin Watson in this study amounted to 2.338. Based on the criteria that have been determined DW values are between -2 to 2 , then it can be concluded that there is autocorrelation in this test.

Multiple regression model is a regression analysis technique to test the relationship between the dependent variable with several independent variables using a multiple regression analysis model. Regression analysis is a tool to measure how the influence of the independent variable on the dependent variable, in the study the purpose of regression analysis is to predict the magnitude of the dependent variable by using data from independent variables whose magnitude is known.

Table 4 - Results of Multiple Regression Calculation

\begin{tabular}{|c|c|c|c|c|c|}
\hline \multirow{2}{*}{ Model } & \multicolumn{2}{|c|}{ Unstandardized Coefficients } & Standardized Coefficients & \multirow{2}{*}{$\mathrm{t}$} & \multirow{2}{*}{ Sig. } \\
\cline { 2 - 5 } & $\mathrm{B}$ & Std. Error & Beta & 1.468 & .154 \\
\hline \multirow{2}{*}{1} & 31.126 & 21.204 & & -1.614 & .119 \\
(Constant) & -.343 & .212 & -.460 & -1.021 & .317 \\
DR & -.179 & .175 & -.287 & .964 & .344 \\
\hline
\end{tabular}

a. Dependent Variable: ROA.

Source: research results (Data processed in SPSS).

Based on Table 4 above, obtained multiple linear regression equation as follows:

$$
Y=31,126-0,343 X 1-0,179 \times 2+0,091 X 3+e
$$

To see how much the partial influence of the three independent variables (Debt Ratio, Debt to Equity Ratio and Total Asset Turnover) that affect Profitability in Pharmaceutical Companies. In relation to the description above, then can be presented interpretation as follows:

Constant value is equal to 31,126 stating or means that if there is no addition of independent variables namely Debt Ratio, Debt to Equity Ratio and Turnover Total Asset then Profitability in Pharmaceutical Companies listed on the Indonesia Stock Exchange in 2012-2016 is positive amounted to 31,126 .

The debt ratio (DR) regression coefficient equal to $-0,343$, meaning that every increase in DR of $1 \%$ and other variables is considered constant, then it will reduce ROA by $-34,3 \%$. 
The debt to equity ratio regression coefficient equal to $-0,179$, means that every increase in DER of $1 \%$ and other variables are considered constant, then reducing the ROA by $-17,9 \%$.

The regression coefficient of total asset turnover (TATO) equal to 0,91 , meaning that every increase in TATO of $1 \%$ and other variables is considered constant, then it will increase ROA by $9,1 \%$.

From the above results indicate that these three variables have a strong influence on the return on assets. This can be seen in the following table:

Table 5 - Determination coefficient test

Model Summary ${ }^{\circ}$

\begin{tabular}{|c|c|c|c|c|c|}
\hline Model & $\mathrm{R}$ & $\mathrm{R}$ Square & Adjusted R Square & Std. Error of the Estimate & Durbin-Watson \\
\hline 1 & $.323^{\mathrm{a}}$ & .104 & .001 & 12.28800 & 2.338 \\
\hline
\end{tabular}

a. Predictors: (Constant), tat, der, dr

b. Dependent Variable: roa

Table 5, above it is known that the value of the Determination Coefficient $\left(R^{2}\right)$ is equal to 0,104 or $10,4 \%$. So it can be concluded that the variables of Debt Ratio, Debt To Equity Ratio and Total Asset Turnover as independent variables have an influence of $10,4 \%$. While the remaining $89,6 \%(100 \%-10.4 \%)$ were obtained from other variables that not examined in this study.

\section{DISCUSSION OF RESULTS}

Based on the results of research related to the title, problems and hypotheses based on the results of data processing, the writer will discuss the results of the research according to the problems proposed.

The results of statistical test with partial test (t test) obtained a coefficient regression value of $-0,334$ with a significance value of 0,119 , because the significance value is greater than $\alpha 0,05$, this means that $\mathrm{H} 1$ is rejected because the Debt Ratio has negative insignificant effect on return on assets in Pharmaceutical companies listed on the Indonesia Stock Exchange.

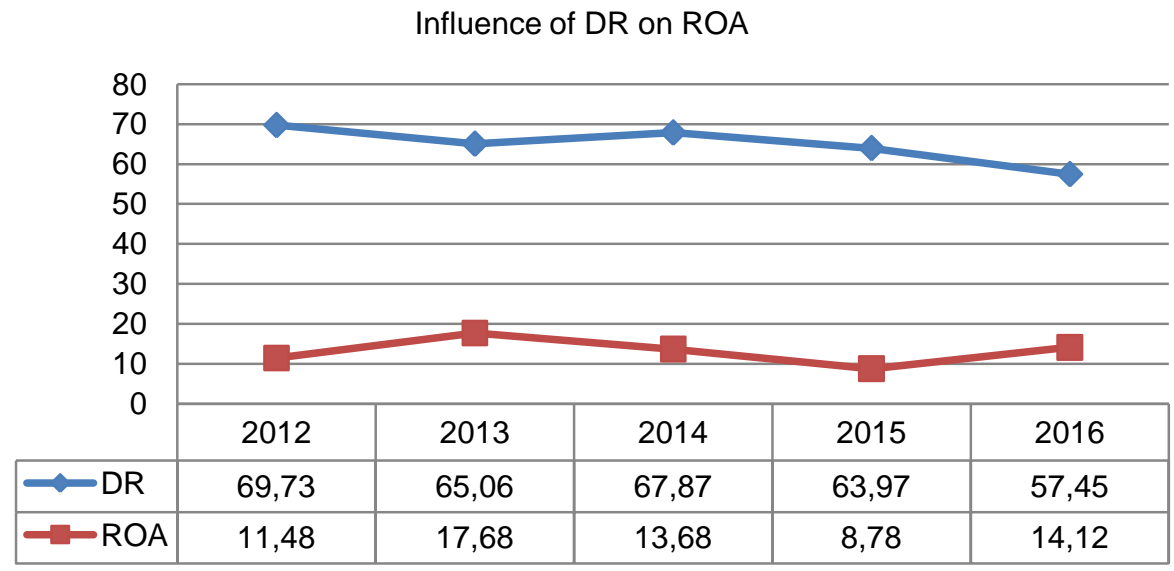

Figure 3 - Graph of Debt Ratio (Source: www.idx.co.id, data processed)

In the graph above it can be seen that the Debt Ratio variable during the study period from 2012 to 2016 experienced a very significant decline, only 2014 experienced a slight increase from the previous year. This also affects Return on Asset, which can be seen that in 2013 increased and in 2014 decreased and in 2015 the ROA experienced a very drastic decline. The results of the regression analysis show that the DR is one of the factors that 
have insignificant effect on ROA in pharmaceutical companies listed on the Indonesia stock exchange. The results of this study were supported by previous researchers namely Nusraningrum (2018). Debt Ratio on ROA the result obtained is DR does not have a significant effect on ROA. The DR research shows how the ability of the company to fulfill its obligations in paying its debt.

The results of statistical testing with partial test ( $t$ test) obtained a value of regression coefficient equal to $-0,179$ with a significance value of 0,317 greater than $\alpha 0,05$. This means that $\mathrm{H} 2$ is rejected because the debt to equity ratio has a negative and insignificant effect on return on assets. This is contrary to the temporary hypothesis that $\mathrm{H} 2$ has a negative and significant effect on return on assets in Pharmaceutical companies listed on the Indonesia Stock Exchange. This can be seen in the graph below:

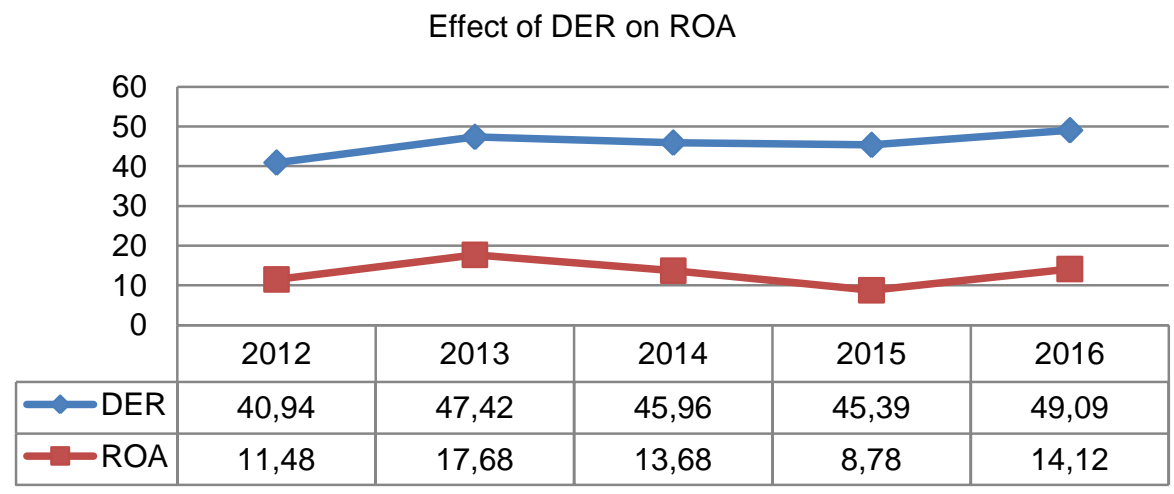

Figure 4 - Graph of Debt to Equity Ratio (Source: www.idx.co.id, data processed)

In the graph above, it can be seen that the variable Debt to Equity Ratio experienced an ups and downs where in 2014 there was an increase, while in 2014-2015 the DER experienced a slight decline, but in 2019 DER increased again. This tends to have no effect on Return on Assets.

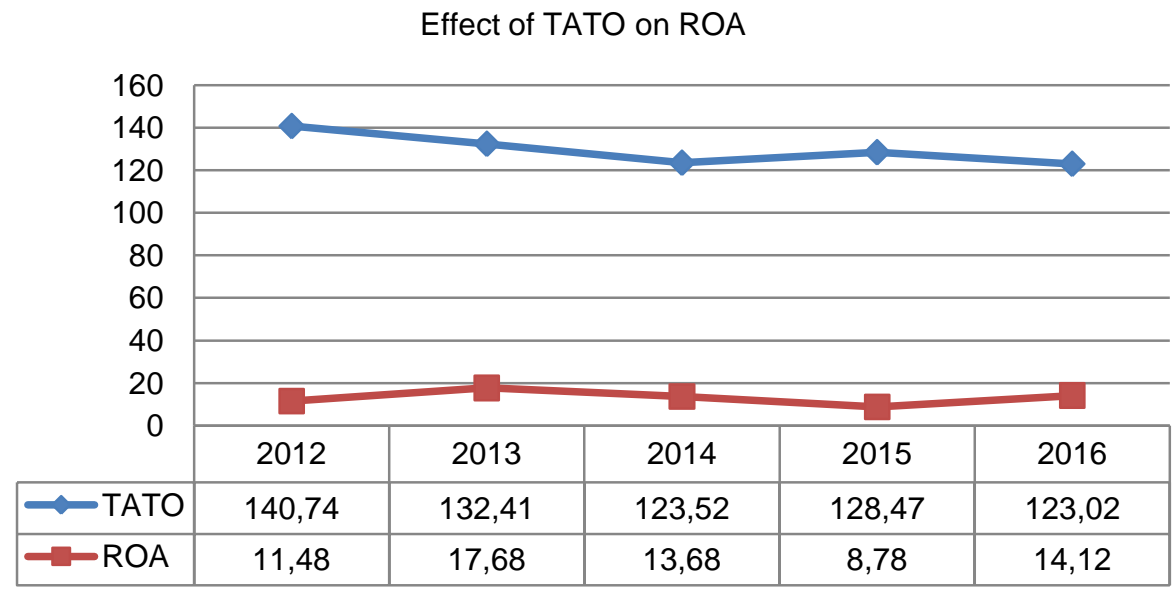

Figure 5 - Graph of Total Asset Turnover (Source: www.idx.co.id, data processed)

The results of this study are supported by previous research conducted by Vătavu (2015), influence of capital structure (Debt to Equity Ratio) on Profitability (ROA), comparative study on textile and garment industry companies listed on the IDX, descriptive analysis method, classic assumption test and hypothesis test. The results obtained namely partially DER has negative insignificant effect on ROA. The DER study shows how the level of a company's ability to fulfill its obligations in paying its debt because DER is one indicator to attract new investors, but is not fully becomes an indicator for investors. 
The results of statistical testing of partial test (t test) obtained a value of regression coefficient equal to 0,091 with a significance value of 0,344 greater than $\alpha 0,05$. This means that $\mathrm{H} 3$ is accepted because the Total Asset Turnover has a positive and insignificant effect on return on assets. This is in contrast to the temporary hypothesis that $\mathrm{H} 3$ has a negative and significant effect on reture on assets in Pharmaceutical companies listed on the Indonesia Stock Exchange.

In the graph above, it can be seen that the variable of Total Asset Turnover in 2013 2016 has decreased; only in 2015 the TATO experienced a slight increase from the previous yearThis also affects the return on assets, and prospective new investors. The results of this study are in line with the research conducted by Jatismara (2011) TATO on ROA results obtained namely TATO has a positive but insignificant effect. So that it can be said that TATO has an effect on ROA.

\section{CONCLUSION AND RECOMMENDATIONS}

From the results of the analysis and discussion of the factors that affect profitability in pharmaceutical companies listed on the Indonesian stock exchange, conclusions can be drawn from this research, as follows:

The results of statistical test with partial test ( $t$ test) obtained a coefficient regression value of $-0,334$ with a significance value of 0,119 , because the significance value is greater than 0,05 , this shows that the variable of Debt Ratio does not affect Return On Assets. This shows that the DR is one of the factors that do not affect ROA in pharmaceutical companies listed on the Indonesian stock exchange.

The results of statistical test with partial test (t test) obtained a coefficient regression value of $-0,179$ with a significance value of 0,317 , because the significance value is greater than 0.05 , his shows that the Debt to Equity Ratio variable does not affect Return on Assets.

The results of statistical test with partial test (t test) obtained a coefficient regression value of 0,091 with a significance value of 0,344 . Because the significance value is greater than 0.05, this shows that the Total Asset Turnover variable does not affect Return on Assets.

\section{RECOMMENDATIONS}

For companies, the management should need to improve financial performance and overall performance of the company's management every year, in order to increase investor confidence in investing in the company. To improve company performance can be done by managing existing capital for activities that can increase added value for companies and investors that are more effective and efficient.

For investors, it is better to pay attention to internal factors, namely DR, DER and TATO that applied to become risk consideration which might occur and the benefits to be obtained before making a decision to invest in a company, especially pharmaceutical companies listed on the Indonesian stock exchange.

For further researchers, this researcher only uses three independent variables, namely DR, DER and TATO in influencing ROA in pharmaceutical companies listed in the Indonesia Stock Exchange.

\section{REFERENCES}

1. Abdullah Halim. 2007, Akuntansi sector Publik Akuntansi keuangan daerah, Edisi Revisi, Jakarta, Selembar Empat.

2. Agnes Sawir. 2005. Analisis kinerja keuangan dan perencanaan keuangan perusahaan. PT. Gramedia Pustaka Jakarta.

3. Allen, F., Bartiloro, L., Gu, X., \& Kowalewski, O. 2018. Does economic structure determine financial structure?. Journal of International Economics, 114, 389-409. 
4. Alti, A. (2006). How persistent is the impact of market timing on capital structure? The Journal of Finance, 61(4), 1681-1710.

5. Ang, A. E., Masulis, R. W., Pham, P. K., \& Zein, J. 2018. Internal capital markets in family business groups during the global financial crisis. UNSW Business School Research Paper Forthcoming.

6. Bhandari, L. C. 1988. Debt/equity ratio and expected common stock returns: Empirical evidence. The journal of finance, 43(2), 507-528.

7. Black, B. S., \& Gilson, R. J. (1998). Venture capital and the structure of capital markets: banks versus stock markets. Journal of financial economics, 47(3), 243-277.

8. Bursa Efek Inonesia (BEI). 2011. Indonesia Capital Market Directory (ICMD). Terdapat di www.idx.co.id

9. Gibson, M. 2008. Manajemen Sumber Daya Manusia. Cetakan ke dua. Jakarta: Erlangga.

10. Jatismara, R. 2011. Analisis pengaruh TATO, DER, Dividend, Sales dan Current Ratio terhadap Return On Asset. Universitas Diponegoro Semarang.

11. Kajananthan, R., \& Velnampy, T. 2018. Liquidity, Solvency and Profitability Analysis Using Cash Flow Ratios and Traditional Ratios: The Telecommunication Sector in Sri Lanka. Research Journal of Finance and Accounting, 5(23).

12. Kasmir. 2014. Bank dan Lembaga Keuaangan Lainya. Edisi Revisi, Cetakan ke empatbelas, PT. Raja Grafindo Persada, Jakarta.

13. Mandu M. Hanafi 2003. Analsis Laporan Keuangan. Edisi repisi. Yokyakarta UPP AMP YKPN.

14. Mandu M. Hanafi 2003. Analsis Laporan Keuangan. Edisi repisi. Yokyakarta UPP AMP YKPN

15. Nassar, S. 2016. The impact of capital structure on Financial Performance of the firms: Evidence from Borsa Istanbul.

16. Nezami, M., Worm, S., \& Palmatier, R. W. 2018. Disentangling the effect of services on B2B firm value: Trade-offs of sales, profits, and earnings volatility. International Journal of Research in Marketing, 35(2), 205-223.

17. Nusraningrum, D., \& Suwesti, E. 2018. Study of Return on Assets in Indonesia Stock Exchange.Saudi Journal of Humanities and Social Sciences, 3(3), 425-434.

18. Prastomo. 2002, Analisis lapran keuangan, cetakan ke 2, Yokyakarta.

19. Rouf, D. 2015. Capital structure and firm performance of listed non-financial companies in Bangladesh. The International Journal of Applied Economics and Finance, 9(1), 25-32.

20. Rouf, D. 2015. Capital structure and firm performance of listed non-financial companies in Bangladesh. The International Journal of Applied Economics and Finance, 9(1), 25-32.

21. Roychowdhury, S., \& Srinivasan, S. 2019. The Role of Gatekeepers in Capital Markets. Journal of Accounting Research, 57(2), 295-322.

22. Saerang, D. P., Tulung, J. E., \& Ogi, I. 2018. The influence of executives' characteristics on bank performance: The case of emerging market. Journal of Governance and Regulation, 7(4).

23. Sugiyono 2012.Metode penelitian bisnis. Bandung: Alfabeta.

24. Syamsuddin, 2009. Manajemen Keuangan Perusahaa. Penerbit PT. Raja Grafindo Persada.Jakarta.

25. Tandelilin. 2010. Portofolio dan Investasi Teori dan Aplikasi. Edisi pertama.Yokyakarta: Kanisius.

26. Vătavu, S. 2015. The impact of capital structure on financial performance in Romanian listed companies. Procedia Economics and Finance, 32, 1314-1322.

27. Wibowo, A. I. L., Putra, A. D., Dewi, M. S., \& Radianto, D. O. 2019. Study of Divergence of Go Public Company's Financial Performance Based on Website Before and After Merger Using Window Period Method TIME Frame 2015-2017. Aptisi Transactions on Technopreneurship, 1(1), 27-51.

28. Yuniningsih, Y., Lestari, V. N. S., Nurmawati, N., \& Wajdi, B. N. 2018. Measuring Automotive Company's Capabilities in Indonesia in Producing Profits Regarding Working Capital. Jurnal Terapan Manajemen Dan Bisnis, 4(1), 67-78. 